\title{
INOVASI PERPUSTAKAAN MELALUI MOOCs: PELUANG PUSTAKAWAN EMBEDDED DI ERA INDUSTRI 4.0
}

\author{
Riana Mardina*
}

\begin{abstract}
Abstrak
Revolusi industri 4.0 memacu kemunculan perkuliahan berbasis digital. Perguruan tinggi dapat mengantisipasi revolusi industri 4.0 dengan mengembangkan pendidikan tinggi jarak jauh atau terbuka yang dapat diimplementasikan dalam tiga model, yaitu: pembelajaran sepenuhnya online learning; blended learning, atau dikombinasikan dalam mata kuliah. Model pembelajaran MOOCs (massive open online courses) dapat dijadikan pilihan untuk pendidikan terbuka (open education). Inti utama model pembelajaran MOOCs adalah kolaborasi dan konektivitas. Pustakawan berperan untuk mendukung dan memfasilitasi model pembelajaran MOOCs. Pustakawan embedded adalah bagian komunitas model pembelajaran MOOCs dan harus berkolaborasi, menjalin hubungan erat dengan mahasiswa dan dosen. Pustakawan embedded dan model pembelajaran MOOCs memiliki esensi sama yaitu komunitas dan kolaborasi. Penguasaan teknologi informasi, online learning, literasi informasi sebagai kapasitas untuk menghadirkan pustakawan embedded dalam mencapai keberhasilan model pembelajaran MOOCs.
\end{abstract}

Keywords: digital technology, MOOC (massive open online courses), embedded librarian, pustakawan

\section{PENDAHULUAN}

Dampak kehadiran revolusi industri 4.0 bagi perguruan tinggi saat ini sudah dirasakan oleh siapa pun, terutama kelompok masyarakat yang berkecimpung dalam industri, seperti e-commerce, pendidikan, jasa, transportasi, perdagangan, dan sebagainya. Dalam tulisan Fathoni pada harian Kompas (Fathoni, Kamis, 2018 hal.8), Menristekdikti mengatakan revolusi industri 4.0 dapat memacu kemunculan perkuliahan berbasis digital. Terdapat empat kompetensi besar yang perlu dipikirkan terkait dengan revolusi industri 4.0 yang dapat memengaruhi spesifikasi pekerjaan ke depannya, dan cenderung diminati oleh pelaku industri, misalnya ekonomi digital (TIK, media digital dan konten); kecerdasan buatan; big data atau data analysis, serta pemrograman. Karakteristik jenis pekerjaan tersebut dipengaruhi teknologi digital yang telah menyebar di seluruh sektor ekonomi.

Hal penting yang ditekan Menristekdikti dalam ulasan yang dimuat Harian Kompas tersebut (Fathoni, Kamis, 2018, hal. 11), adanya revolusi industri 4.0 yang bisa di adopsi dalam pendidikan tinggi adalah pengembangan pendidikan tinggi jarak jauh (open and distance learning) yang dapat diimplementasikan dalam tiga model, yaitu: pembelajaran full online learning; dikombinasikan dalam mata kuliah tertentu, atau model blended learning. Pendapat Bapak Menristekdikti dalam mengantisipasi revolusi industri 4.0 dengan memanfaatkan teknologi digital khususnya pada modelmodel pembelajaran mahasiswa.

Pembelajaran jarak jauh pada perguruan tinggi adalah contoh model pembelajaran dengan menggunakan teknologi informasi dan komunikasi. Tidak menutup kemungkinan bagi perguruan tinggi biasa dapat mengembangkan metode pembelajaran berbasis online dengan model terbuka (open education), atau mengombinasi dengan model pembelajaran tatap muka, dengan perhitungan jumlah persentase tatap muka dan online, seperti saat ini yang dijalankan sebagian besar perguruan tinggi di Indonesia atau yang disebut e-learning.

Banyak istilah digunakan untuk pengelolaan pembelajaran jarak jauh atau online learning, open education, distance learning, hybrid learning ataupun

* Pustakawan Universitas Kristen Krida Wacana

Email: riana@ukrida.ac.id 
blended learning. Keberadaan model pembelajaran berbasis online, dengan prinsip 'full online', apalagi jika menargetkan jumlah mahasiswa dalam jumlah besar, ataupun konsep pendidikan berbasis online dengan jumlah mahasiswa dengan kapasitas besar, seperti halnya dengan ulasan ilmiah di bawah ini yaitu pembelajaran massive open online courses (selanjutnya menggunakan istilah MOOCs).

Dalam bahasan di bawah ini, dipaparkan tentang keberadaan model pembelajaran MOOCs yang dapat dikembangkan sebagai inovasi layanan baru perpustakaan, serta kesiapan ataupun perubahan peran pustakawan dalam memfasilitasi model pembelajaran MOOCs bagi mahasiswa perguruan tinggi. Perlu dipertimbangkan posisi perpustakaan seperti apa dalam mengantipasi pembelajaran jarak jauh tersebut, kebijakan pengembangan koleksi, dukungan infrakstruktur teknologi informasi.

\section{METODE PENELITIAN}

Penulisan artikel ini menggunakan metode telaah ilmiah atau tinjauan pustaka, yaitu dengan melalui penelusuran pengetahuan yang telah dipublikasikan sebagai pustaka atau artikel ilmiah, dengan mensintesis pengetahuan-pengetahuan yang fokus utama pada model pembelajaran MOOCs, inovasi pustakawan, serta konsep dan implementasi pustakawan embedded dalam model pembelajaran MOOCs. Sintesis yang didapatkan penulis, dituliskan sebagai kajian bersifat terobosan pengembangan peran pustakawan embedded sebagai inovasi layanan perpustakaan untuk mendukung model pembelajaran MOOCs ini.

\section{PEMBAHASAN}

\section{Massive Open Online Courses (MOOCs)}

Pembelajaran secara online banyak menggunakan terminologi atau istilah berbeda, seperti pembelajaran jarak jauh, pembelajaran online, pembelajaran tanpa ruang kelas, dan sebagainya. yang disesuaikan dengan pencipta model pembelajaran secara online. Pendidikan online atau pembelajaran berbasis teknologi (educational technology) sudah lama dijalankan beberapa perguruan tinggi di Indonesia. Tren penggunaan teknologi internet dengan berbagai aplikasi, baik sistem informasi manajemen perguruan tinggi, maupun dalam sistem perkuliahan. Model pembelajaran online dengan platform MOOCs dalam inovasi sistem perkuliahan saat ini menjadi tren, karena faktor manfaat seperti target kebutuhan untuk menjangkau jumlah mahasiswa lebih banyak, sebaran wilayah di beberapa tempat ataupun lokasi berjauhan. Porter (2015) menyatakan bahwa model-model pembelajaran MOOCs menjadi sistem pembelajaran pada perguruan tinggi yang cepat berubah dan tidak mudah diprediksi perubahannya. Jika ditinjau dari pemahaman disrupsi teknologi, maka model pembelajaran MOOCs dapat disebut sebagai disruptif baru dalam industri lainnya, dengan melihat pendidikan tinggi dianggap 'komoditas berbasis internet'.

Kemunculan MOOCs dipelopori oleh George Simmons dan Stephen Downes (Porter, 2015; Becker, 2013), pioner dalam model pembelajaran berbasis online yang telah diakui dan diterima sebagai metode pembelajaran baru. Inti utama pemikiran Simmons dan Downes adalah konektivitas, ide yang diacu dari teori belajar, atau disebut juga open teaching. Pendapat Bond \& Leibowitz (2013) menyatakan keberadaan model pembelajaran MOOCs ditekankan pada aspek penyampaian perkuliahan. Berdasarkan kedua pernyataan di atas, dapat disimpulkan bahwa ide utama model pembelajaran MOOCs adalah konektivitas atau hubungan dan pola penyampaian materi perkuliahan yang tersimpan dalam platform MOOCs tersebut.

Karakteristik model pembelajaran MOOCs dinyatakan Porter (2015) yaitu:

1. Massive, artinya diperuntukkan untuk mahasiswa dalam skala besar, bisa jumlah ratusan, bahkan ribuan partisipan, ataupun tanpa batasan jumlah mahasiswa yang ditentukan.

2. Open, artinya, dimaksudkan untuk akses terbuka secara gratis atau berbayar pada konten MOOCs serta juga tidak ada pembatasan pada konten MOOCs. Pada platform MOOCs, tidak ada persyaratan untuk akses ke konten MOOCs, karena bersifat terbuka untuk semua latar belakang pendidikan, usia maupun lokasi.

3. Online, artinya, penyampaian materi perkuliahan MOOCs secara online, dan tidak ada proses tatap muka. Proses online yang memudahkan mahasiswa berkomunikasi dengan lain, serta akses sumber belajar mudah tersedia di internet.

4. Courses, artinya, kunci utama pembeda, antar platform MOOCs dengan MOOCs lainnya, terutama perbedaan pada sumber-sumber pendidikan yang bersifat terbuka. 
Sedangkan karakteristik model pembelajaran MOOCs menurut Gore (2015) memiliki kesamaan dengan yang disampaikan Porter, dibagi menjadi empat karakteristik yaitu:

1. Massive, artinya tidak membatasi jumlah yang mendaftar untuk perkuliahan (dalam kasus tertentu bisa melebihi 100.000 mahasiswa)

2. Open, artinya, mendapatkan manfaat lebih luas dengan ketersediaan koleksi OER (open education resources), dan pendaftaran perkuliahan bersifat terbuka; dalam beberapa platform MOOCs, mensyaratkan adanya pendaftaran awal, pembayaran tinggi, biaya registrasi, ujian dan pemberian sertifikat)

3. Online, artinya tidak mensyaratkan pertemuan secara tatap muka.

4. Courses, artinya, adanya konsep secara pedagogis yang dirancang selama perkuliahan berjalan.

Demikian halnya dengan yang dinyatakan Barnes (2013), karakteristik model pembelajaran MOOCs, yaitu:

a. Tidak ada persyaratan formal untuk mendaftar;

b. Partisipasi bersifat bebas;

c. Materi disampaikan secara online;

d. Skalabitas MOOCs bersifat masif, artinya didesain untuk jutaan pengguna.

Model pembelajaran MOOCs memiliki atributatribut disesuaikan dengan karakterisik sebagai berikut:

1. xMOOCs menekankan pada: (a) aspek skabilitas, yaitu jumlah mahasiswa yang berpartisipasi dalam skala besar, seperti yang dikemukakan Rhoads (2015) model MOOCs dengan skalabilitas, berfokus pada kemampuan menjangkau mahasiswa dalam jumlah banyak secara sekaligus; (b) akses terbuka dan akses terbatas pada konten berlisensi; (c) pembelajaran bersifat individual dalam platform tunggal dan (d) membutuhkan kurikulum yang mensyaratkan pengetahuan dan keterampilan.

2. cMOOCs menekankan pada: (a) konektivitas dan komunitas, artinya proses perkuliahan dosen dan mahasiswa dilakukan secara online (tidak ada tatap muka) dan komunitas sudah ditentukan sebagai target yang akan dijangkau, (b) akses terbuka dan berlisensi; (c) pembelajaran yang menembus berbagai multi platform dan layanan; (d) mengembangkan layanan, pengetahuan dan pengalaman untuk berbagi

Kedua model MOOCs di atas, menyediakan koleksi diakses online secara bebas, bisa atau tidak mensyaratkan pendaftaran sebagai mahasiswa, artinya partisipan model pembelajaran MOOCs dapat berasal dari internal perguruan tinggi atau eksternal yaitu masyarakat luas, bisa saja terpisah jarak, antar kota maupun antar negara. Model pembelajaran MOOCs juga menyediakan pilihan bisa gratis atau berbayar, disesuaikan dengan kebijakan penyedia aplikasi MOOCs maupun pembuat materi perkuliahan MOOCs.

Kemajuan teknologi digital sebagai dampak revolusi industri 4.0 menjadi peluang untuk mengembangkan model pembelajaran MOOCs. Sisi positif dengan adanya MOOCs ditinjau pada aspek penyedia (Porter, 2015) yaitu: (a) perkuliahan online bersifat individual, disediakan untuk siapa pun dengan tujuan untuk belajar; (b) platform MOOCs sudah banyak digunakan, misalnya EdX, Coursera, Udasity, Future Learn dan sebagainya; (c) penyedia atau pembuat materi pembelajaran MOOCs adalah perguruan tinggi atau organisasi.

Model pembelajaran MOOCs ditinjau dari awal kehadiran, disediakan secara terbuka (open learning), berlisensi dan, atau dilekatkan (embedded) dalam perkuliahan perguruan tinggi yang bersangkutan (Barnes, 2013). Kehadiran MOOCs awalnya dimulai di perguruan tinggi, dan hingga saat ini, bisa berdiri sendiri sebagai platform pembelajaran online yang digunakan oleh perguruan tinggi, ataupun model pembelajaran MOOCs dapat dikembangkan sebagai platform kolaborasi antar dua atau lebih perguruan tinggi.

Keberlangsungan model pembelajaran MOOCs untuk masa akan datang dipengaruhi kombinasi dari model pembelajaran yang sudah ada; metode penyampaian dan model bisnis apa yang diharapkan. Seperti yang disebutkan pada paparan di atas, platform MOOCS sudah banyak dibuat, seperti kolaborasi yang dibangun antara MIT dan Harvard University yaitu edX sebagai ouput MOOCs kedua perguruan tinggi tersebut. Warburton \& Mor (2015) menyebutkan bahwa desain untuk mengembangkan MOOCs perlu dipenuhi beberapa aspek utama. Pemenuhan itu disebut istilah enam dimensi desain MOOCs, yaitu: struktur, orientasi, partisipasi, pembelajaran, komunitas dan manajemen.

Keberadaan model pembelajaran MOOCs tidak bisa dilepaskan dengan perpustakaan, jika dikaitkan dengan sumber-sumber referensi perkuliahan online, sangat diperlukan perpustakaan dan peran pustakawan untuk mendukung dan memfasilitasi perkuliahan MOOCs tersebut. Peran perpustakaan dan pustakawan seperti apa yang perlu disiapkan harusnya menyesuaikan dengan model pembelajaran MOOCs, terutama perguruan tinggi yang masih mengombinasikan perkuliahan tradisional 
dengan perkuliahan online, ataupun perguruan tinggi yang keseluruhan perkuliahan dilaksanakan secara online, tanpa tatap muka, ataupun menyediakan perkuliahan MOOCs untuk eksternal perguruan tinggi tersebut.

\section{Model Pustakawan Embedded Sebuah Pilihan}

Kreativitas pustakawan dalam era digital dituntut berubah seiring beragamnya generasi mahasiswa yang menjadi sasaran pengguna perpustakaan. Kreativitas pustakawan dalam mengelola inovasi layanan dapat diwujudkan melalui penggunaan teknologi digital, internet dan media sosial. Konsep pustakawan dalam perkembangan teknologi digital, terutama pada pembelajaran online, bukan lagi melakukan pekerjaan sebagai pustakawan tradisional. Seperti yang dikemukakan Dewey (2004), bahwa peran pustakawan perguruan tinggi dalam proses pembelajaran dan penelitian, menjadi cara yang relevan, bila pustakawan menjalankan layanan perpustakaan dengan proses saling melekatkan (embedding), melalui kolaborasi yang paling efektif yang dapat dieksplorasi dalam lingkungan fisik dan virtual. Dalam era teknologi digital, pustakawan tidak hanya sebagai pendukung, tetapi harus menjadi partner atau rekan dengan dosen, pengajar, atau peneliti dan mahasiswa, serta peran baru untuk menghadirkan kolaborasi dan koneksi yang kuat terhadap penggunanya. Pustakawan di era digital perlu memahami konsep distance education maupun distance librarian agar bisa mengeksplorasi peran sebagai pustakawan embedded, karena memiliki esensi sama dalam proses penyampaian perkuliahan berbasis online antara embedded librarian dengan distance librarian.

Konsep pustakawan embedded (Delaney \& Bates, 2015) adalah pustakawan yang memfokuskan layanan pada kebutuhan pengguna, baik pada satu ataupun lebih fokus kelompok yang spesifik, membangun hubungan dengan kelompok, mengembangkan pemahaman yang mendalam akan pekerjaanya dan menyediakan layanan yang dikustomisasi lebih rinci dan ditargetkan memenuhi kebutuhan yang paling penting, kemudian lebih mengedepankan transaksi layanan yang dipercayai, kolaborasi erat serta berbagi tanggung jawab untuk hasil luaran. Terdapat dua hal utama keberadaan pustakawan embedded (Delaney \& Bates, 2015) yaitu:

1. Kebutuhan untuk melibatkan dengan pengguna dalam skope kebutuhan pengguna.

2. Kebutuhan untuk berkolaborasi dan menjangkau pengguna bukan anggota dari perpustakaan itu sendiri (eksternal).
Mune (2015) dan Barnes (2013) juga menyebutkan bahwa tipe pustakawan dalam melakukan kolaborasi pada model pembelajaran MOOCs adalah dengan model embedded librarian. Secara praktik layanan dapat dilakukan dengan menyediakan library tutorials dan panduan penelitian di website perpustakaan. Embedded librarian harus menyatu dalam pembelajaran online, serta berperan sebagai pengajar dan aktif dalam semua materi perkuliahan online. Model pustakawan embedded menjadi pilihan utama, dengan mengacu pada karakteristik pembelajaran MOOCs yaitu kolaborasi , seperti yang diungkap Drewes \& Hoffman (2010); Stephen \& Jones (2015), dalam lingkungan pembelajaran online, pustakawan embedded harus terlibat secara aktif menjalin kedekatan hubungan dalam berbagai kegiatan dengan pengguna perpustakaan serta berkolaborasi dengan fakultas. Bentuk kolaborasi seperti berpartisipasi dalam diskusi online, menjawab pertanyaan mahasiswa; menawarkan instruksi/pelatihan kelompok kelas dengan berbasis web conference, atau terlibat dalam memberi bantuan teknis, misalnya menawarkan solusi jika terjadi gangguan dalam penggunaan aplikasi. Pustakawan harus bekerja secara tim dengan pengajar dan pengelola platform MOOCs.

Ditekankan juga, pustakawan embedded bukan sekedar pendukung kegiatan, tetapi menjadi anggota komunitas yang dilayani. Konsep komunitas dan kolaborasi yang dilakukan pustakawan embedded sejalan dengan salah satu karakteristik model pembelajaran MOOCs yaitu pada kolaborasi dan komunitas. Konsep pustakawan embedded dalam konteks teknologi adalah berfokus pada pengguna, mendekatkan perpustakaan kepada pengguna, dimanapun pengguna berada, baik di kantor, rumah bahkan mengontak pengguna melalui saran teknologi mobile (Kesselman \& Watstein, 2009). Berkembangnya perkuliahan berbasis online, mendorong pustakawan harus beradaptasi dengan meningkatkan pemahaman, pengetahuan serta keterampilan dalam teknik-teknik intruksional. Demikian halnya dengan layanan perpustakaan dapat dikembangkan lebih lanjut mengikuti lingkungan online (online learning environment), mengingat pustakawan embedded sebagai bagian dari komunitas pembelajaran online. (York \& Vance, 2009; Francis (2012)

\section{Model Pustakawan Embedded dalam Pembelajaran MOOCs}

Dalam ulasan tentang konsep dan model pustakawan embedded, sudah dengan jelas dipaparkan, bahwa 
pustakawan embedded merupakan model yang tepat untuk dalam pembelajaran online, terutama perguruan tinggi yang menerapkan model pembelajaran MOOCs. Berbagai pendapat mengarah pada satu tujuan yang sama, bahwa pustakawan embedded harus berperan lebih dalam lagi, melekatkan (embedded) baik peran pustakawan maupun layanan perpustakaan melalui kolaborasi dengan pengguna yang berada dalam lingkungan pembelajaran online (Barnes, 2013, Becker, 2013), bahwa pustakawan harus mampu menjalin kolaborasi yang dalam dengan penggunanya, karena partisipasi pustakawan dengan mahasiswa dominan dilakukan secara online. Tipe kolaborasi ditinjau dari cara penyampaian, misalnya memberi rekomendasi bagi mahasiswa pengguna platform untuk memilih akses ke database online journal yang bersifat open access atau berbayar. Barnes mengusulkan pustakawan embedded merupakan pilihan yang bagus untuk mereposisikan peran pustakawan dalam model pembelajaran online di era teknologi digital ini.

Rhoads (2015) menyebutkan kapasitas pustakawan dalam mendukung keberadaan model pembelajaran MOOCs harus memiliki pengetahuan dan kemampuan, seperti: manajemen dan mampu melakukan sosialisasi tentang hak cipta, serta mengembangkan library instruction atau literasi informasi, misalnya mengajarkan tentang membuat hyperlink untuk topik-topik yang tersedia dalam sebuah materi perkuliahan online. Salah satu karakteristik dari model pembelajaran MOOCs adalah partisipasi, pustakawan dapat menghadirkan kondisi partisipasi dalam model pembelajaran MOOCs dengan cara: menciptakan aplikasi online yang menghadirkan partisipasi secara online antara mahasiswa dengan pustakawan, melalui portal perpustakaan yang terintegrasi dalam platform MOOCs tersebut. Model partisipasi online, seperti video, kuis, tugas-tugas yang memberi kesempatan bagi mahasiswa dan pustakawan dapat berinteraksi secara online.

Barnes (2013) juga mengemukakan peran pustakawan dalam model pembelajaran MOOCs dituntut harus memiliki pemahaman tentang hak cipta (copyright clearance); konten materi perkuliahan yang berlisensi; paham terhadap konten-konten yang diakses secara terbuka; kesediaan membantu dan memastikan konten MOOCs dapat diakses oleh semua pengguna MOOCs termasuk didalamnya adalah teknologi dengan kategori 'assertive' atau aplikasi bantuan'; mampu menyediakan literasi informasi yang sesuai dengan model pembelajaran MOOCs; menggiatkan pengguna konten sumber rujukan yang berlisensi; mampu menyediakan kebijakan lembaga yang terkait dengan partisipan MOOCs, siapa yang bisa mengakses, prosedur untuk mengakses, terutama jika memiliki pengguna di luar institusi.

Demikian halnya dengan Mune (2015), mengemukakan bahwa layanan yang dapat diberikan kepada mahasiswa MOOCs: (a) materi keterampilan literasi informasi dan digital dari database berbayar maupun open access; (b) menyediakan layanan referensi virtual, yang tidak membebani pustakawan. Layanan ini harus ada kontrol ataupun pemberian jam layanan referensi disesuaikan dengan kapasitas jumlah pustakawan. Tersedianya pilihan jenis layanan referensi untuk kategori mahasiswa yang tidak masuk program penyetaraan; untuk database berbasis open access, layanan mandiri dengan model tanya jawab (F\& Q); (c) pustakawan embedded, perlu melakukan revisi pengembangan koleksi secara praktis, terutama pengadaan sumber informasi berbayar, berbasis open access yang disediakan dalam platform MOOCs.

Kompetensi pustakawan embedded dalam penyediaan MOOCs dinyatakan Bond \& Leibowitz (2013) harus mampu: (1) mengidentifikasi bahan bacaan yang harus dijadikan rujukan dalam materi-materi perkuliahan online; (2) memberikan advokasi tentang konten 'open access'; isu-isu fair use, hak cipta untuk konten database berbayar, kebijakan akses terhadap konten berbayar, penggunaan konten yang memiliki hak cipta (Gore, 2015). Konsultasi penting dalam advokasi adalah jika mahasiswa pengguna MOOCs dari negara lain, yang memiliki perbedaan pandangan terhadap open access maupun hak cipta (Gore, 2015); (3) pemahaman dan pelatihan tentang sitasi dengan berbagai pilihan, seperti Mendeley, Zotero, dan sebagainya. Demikian halnya dengan pendapat Mune (2015), pustakawan embedded merupakan pilihan utama dalam mendukung model pembelajaran MOOCs, terutama literasi informasi dalam lingkungan pembelajaran online. Tutorial literasi informasi berbasis web dan dilengkapi dengan evaluasi mandiri terhadap tutorial tersebut, sebagai inovasi layanan untuk mendukung model pembelajaran MOOCs.

Penguasaan literasi informasi dan digital menjadi syarat utama yang wajib diberikan kepada mahasiswa peserta platform MOOCs (Barnes, 2013; Rhoads, 2015; Mune, 2015; Bond \& Leibowitz, 2013; Gore, 2015). Jika disarikan dari konten literasi informasi, ternyata literasi informasi sangat mendukung bagi mahasiswa yang mengikuti model pembelajaran MOOCs. Seperti mengacu penguasaan tahapan literasi informasi keterampilan penelusuran informasi, mensintesa, penggunaan informasi dalam tulisan, mensitasi, plagiarism. Tahapan literasi informasi dan digital lainnya seperti berpikir 
kritis, mendorong mahasiswa harus bersikap dan berpikir mandiri terhadap tugas-tugas perkuliahan online; mampu bekerja secara tim dengan dosen yang membuat materi perkuliahan MOOCs, serta jenis informasi bukan teks (gambar, video, sound, dan sebagainya)

\section{Implementasi Pustakawan Embedded dalam Pembelajaran MOOCs}

Pustakawan embedded menjadi pilihan utama dalam mendukung model pembelajaran MOOCs, maka pustakawan wajib memiliki pengetahuan dan keterampilan yang diajarkan kepada mahasiswa pengguna platform MOOCs. Fokus utama sebagai pustakawan embedded adalah menghadirkan kolaborasi dan konektivitas atau membina hubungan baik dari dosen maupun mahasiswa. Beberapa yang dapat dikembangkan untuk menghasilkan inovasi layanan perpustakaan melalui pustakawan embedded:

1. Memahami esensi desain pembelajaran online (online learning design) dalam lingkungan digital (digital environment).

2. Menempatkan posisi pustakawan sebagai mitra sejajar dengan dosen, terutama jika ada menu diskusi online antara dosen, pustakawan dan mahasiswa dalam mendiskusi topik tertentu.

3. Membuat konten layanan perpustakaan online yang menghadirkan kolaborasi dan partisipasi, atau membangun hubungan baik dari dosen maupun mahasiswa pengguna platform MOOCs. Misalnya disediakan menu 'help' misalnya chat online atau email.

4. Fokuskan semua layanan kepada pengguna, artinya menyiapkan layanan online yang sengaja dikustomisasi sesuai karakteristik mahasiswa dan dosen peserta platform MOOCs. Pustakawan harus responsif terhadap kebutuhan pengguna online, mampu membuat profiling mahasiswa dari tingkat awal hingga lanjut, terutama tingkat pemahaman akan layanan online perpustakaan.

5. Perlu diperhatikan dalam memberikan rekomendasi koleksi rujukan kepada dosen pengampu mata kuliah online, terkait aspek hak cipta, etika informasi, koleksi berlisensi, open access, creative commons untuk jenisjenis database online yang disediakan bagi dosen dan mahasiswa.

6. Memahami dan menguasai cara mengajarkan literasi informasi secara online. Bentuk literasi informasi berbasis web (tutorials) yang mudah dipahami oleh mahasiswa. Materi literasi informasi yang utama seperti berpikir kritis terhadap informasi digital, mensintesa informasi, plagiarisme, dan penggunaan informasi dalam pembuatan tugas mahasiswa tersebut.

7. Mampu mengajarkan secara online tentang teknik membaca cepat, terutama membaca teks secara digital.

8. Pengaturan jam kerja untuk layanan chat atau email. Harus ada kontrol jam layanan disesuaikan dengan kapasitas jumlah pustakawan, untuk menghindari kelelahan bagi pustakawan.

\section{PENUTUP}

Model pembelajaran online tidak bisa kita hindari, terutama dengan adanya revolusi industri 4.0 yang berbasis digital. Pustakawan embedded menjadi pilihan utama sebagai inovasi peran pustakawan dan layanan dalam mendukung perguruan tinggi yang telah memiliki atau ingin mengembankan model pembelajaran MOOCs di masa akan datang.

Inovasi layanan dan peran pustakawan embedded, memiliki dampak dalam manajemen perpustakaan. Diperlukan sistem dan prosedur untuk mengembangkan layanan secara online maupun kolaborasi yang akan dibangun, disesuaikan dengan model platform xMOOCs atau cMOOCs, seperti batasan jumlah mahasiswa yang akan dilayani (aspek skalabilitas), jika mahasiswa bukan kategori internal perguruan tinggi tersebut.

Pengaturan pemberian hak untuk mengakses koleksi database online yang dilanggan ataupun tersedia secara open access, jika memiliki mahasiswa eksternal perguruan tinggi ataupun bagi mahasiswa peserta MOOCs yang tidak membutuhkan persyaratan pendaftaran sebagai mahasiswa (berbayar), ataupun, untuk mahasiswa yang berasal dari luar negeri, terutama pembatasan koneksi internet (hak cipta) terhadap konten MOOCs dalam kategori berbayar. Pengaturan berbagi koleksi database online, jika pilihan platform MOOCs merupakan kombinasi dua atau lebih perguruan tinggi.

\section{DAFTAR PUSTAKA}

Barnes, C. 2013. MOOCs: The Challenges for academic librarians. Australian Academic \& Research Libraries. 44 (3): 163-175.

Becker, B.W. 2013. Connecting MOOCs and library services. Behavioral \& Social Sciences Librarian. 32:135-138,

Bond, P \& Leibowitz, F.2013. MOOCs and serials. Serials Review. 39: 258-260. 
Delaney, G \& Bates, J.2015. Envisioning the academic library: a reflection on roles, relevancy and relationships. New Review of Academic Librarianship.21:30-51.

Dewey, B.I. 2004. The Embedded librarian: strategic campus collaborations. Librarian, Resource Sharing \& Information Networks. 17: 1-2, 5-17. http://dx.doi. org/10.1300/J121v17n01_02.

Drewes, K \& Hoffman, D. 2010. Academic embedded librarianship: an introduction. Public Services Quarterly, 6:75-82.

Fathoni, R. (2018, March 6). Saatnya memacu perkuliahan digital. Harian Kompas, h.6 dan h.8.

Francis, M. 2012. Making embedded librarians a part of an online community of learners. Journal of Library \& Information Services in Distance Learning, 6:19-27.

Gore, H. 2015. Massive open online courses (MOOCs) and their impact on academic library services : exploring the issues and challenges. New Review of Academic Librarianship. 20 (1): 4-28. https://doi: 10.1080/13614533.2013.851609

Kesselman, M.A., Watstein, S.B. 2009. Creating opportunities: embedded librarians. Journal of Library Administration. 49:383-400.
Mune, C. 2015. Massive open online librarianship: emerging practices in response to MOOCs. Journal of Library \& Information Services in Distance Learning. 9:89-100. https://doi:10.1080/1533290X.2014.946350.

Porter, S. 2015. To MOOC or not to MOOC: How can online learning help to build the future higher education?. Amsterdam : Chandos Publishing.

Rhoads, R.A.2015. MOOCs: High technology \& higher learning. Baltimore : John Hopkins University Press.

Stephens, M. \& Jones, K.M.L. 2015. Emerging roles: key insights from librarians in a massive open online course. Journal of Library \& Information Services in Distance Learning, 9:133-147.

York, A.C., Vance, J.M. 2009. Taking library instruction into the online classroom: best practices for embedded librarians. Journal of Library Administration, 49:197209.

Warburton, S., \& Mor, Y. 2015. A set of patterns for the structured design of MOOCs. Open Learning, 30 (3): 206-220, http://dx.doi.org/10.1080/02680513.2015.110 0070 . 